\title{
Perayaan Pesta Nelayan Sebagai Daya Tarik Wisata Dalam Mempromosikan Pariwisata di Palabuhanratu Sukabumi
}

\author{
Andhika Chandra Lesmana, Nadya Ajeng Astuti \\ STIEPAR YAPARI \\ andhika.lesmana87@yahoo.com,nanadya145@gmail.com
}

\begin{abstract}
This research was conducted in Palabuhanratu Sukabumi Regency, the aim of the study is to know about the organization of cultural tourism of fishermen party,tourist attraction of fisherman's day activities, and the effectiveness of tourism promotion of fisherman's day.This research uses descriptive qualitative research method and key informan as much as four people consisting of Tourism Office of Sukabumi Regency, Culture Youth and Sports Office, Fishermanday Chair, and Fishery Port of Nusantara Palabuhanratu. The result of research shows that, the organization of cultural tourism fishing party is very attractive for touristand held once a year which is followed by traditional ceremonies, cultural performances, parade of queen of fishermen and stakeholders, there is also a seaborn that the offerings to the sea and entourage of cultural performance and tourist.
\end{abstract}

Keywords - celebration of a fishing day; tourism attraction; tourism promotion

Abstrak-Penelitian ini diakukan di Palabuhanratu Kabupaten Sukabumi, tujuannya adalah untuk mengkaji: penyelenggaraan pariwisata budaya pesta nelayan, daya tarik wisata kegiatan hari nelayan, dan efektifitas promosi daya tarik wisata hari nelayan. Penelitian ini menggunakan metode penelitian kualitatif deskriptif dan informasi kunci sebanyak empat orang terdiri dari Dinas Pariwisata Kabupaten Sukabumi, Dibudpora,Ketua Hari Nelayan, dan Pelabuhan Perikanan Nusantara Palabuhanratu. Hasil peneitian menunjukkan bahwa, penyelenggaraan pariwisata budaya pesta nelayan sangat menarik bagi wisatawan dan diadakan satu tahun sekali yang diikuti dengan upacara adat, pagelaran budaya, parade putri nelayan dan pemangku adat, juga ada labuh saji yang sesajennya dilepas ke tengah laut beserta para rombongan pagelaran budaya dan pengunjung.

Kata kunci-perayaan pesta nelayan; daya tarik wisata; promosi pariwisata

\section{PEndahuluan}

Sektor pariwisata merupakan sumber devisa, dan telah mengambil peran penting dalam membangun perekonomian suatu daerah. Kini, masing-masing pemerintah daerah sudah berbenah diri untuk menjadikan daerahnya sebagai tujuan wisata (Lesmana, Edison, \& Dara, 2017). Salah satu daerah yang sudah berbenah diri menjadikan daerahnya sebagai tujuan wisata adalah Kabupaten Sukabumi.

Kabupaten Sukabumi merupakan Kabupaten terluas di Provinsi Jawa Barat yang memiliki sejuta potensi wisata. Kabupaten Sukabumi kaya akan potensi daya tarik wisata yang meliputi Wisata Gunung, Rimba, Laut, Pantai, Sungai, dan Seni atau lebih dikenal dengan (GURILAPSS). Keindahan alam yang luar biasa, tanah yang subur serta luas maka dibuatlah sebuah kawasan wisata yang terdiri dari 8 Kecamatan dan jika dilihat dari udara maka akan berbentuk seperti tapal kuda dan bebatuan yang memiliki usia ratusan tahun dan jika dilihat seksama akan membuat takjub, kawasan wisata ini diberi nama Geopark Ciletuh dan Palabuhanratu di Kabupaten Sukabumi.

Palabuhanratu juga terkenal dengan festival laut Seren Taun atau Hari Nelayan yaitu upacara melabuhkan kepala kerbau dan sesaji lainnya ke tengah laut dengan seiring waktu kepala kerbau pun diganti menjadi pelepasan tukik/anak penyu dengan tujuan untuk melestarikan penyu agar tidak punah atau juga sering di sebut Pesta Rakyat Palabuhanratu. Sebagian besar penduduk Palabuhanratu berprofesi sebagai nelayan sehingga perayaan pesta nelayan ini terus dilakukan dan sudah menjadi budaya dan tradisi warga setempat. Tetapi dengan adanya perayaan pesta nelayan sebagai daya tarik wisata nampaknya masih belum dikemas dan dipromosikan dengan baik, karena pesta nelayan ini sementara hanya bisa dinikmati oleh wisatawan lokal saja.

Palabuhanratu juga terkenal dengan festival laut Seren Taun atau Hari Nelayan yaitu upacara melabuhkan kepala kerbau dan sesaji lainnya ke tengah laut dengan seiring waktu kepala kerbau pun diganti menjadi pelepasan tukik/anak penyu 
dengan tujuan untuk melestarikan penyu agar tidak punah atau juga sering di sebut Pesta Rakyat Palabuhanratu. Pelestarian budaya yang harus dilakukan agar generasi muda masih bisa menyaksikan warisan nenek moyang terdahulu. Dengan adanya budaya, hal ini dapat meningkatkan perekonomian daerah karena dapat dikemas menjadi daya tarik wisata dan mendatangkan banyak wisatawan, salah satunya yaitu perayaan pesta nelayan yang dilakukan setiap satu tahun sekali oleh masyarakat Palabuhanratu. Selain itu juga sebagian besar penduduk Palabuhanratu berprofesi sebagai nelayan sehingga perayaan pesta nelayan ini terus dilakukan dan sudah menjadi budaya. Perayaan pesta nelayan di adakan setiap tanggal 6 April untuk ungkapan rasa syukur para nelayan kepada Tuhan atas hasil laut yang mereka peroleh, karena hal ini telah menjadi budaya yang sangat khas.

Dengan adanya perayaan pesta nelayan sebagai daya tarik wisata masih belum dikemas dan dipromosikan dengan baik, karena pesta nelayan ini hanya bisa dinikmati oleh wisatawan lokal saja. Berdasarkan uraian di atas peneliti tertarik untuk melakukan penelitian dengan judul "Perayaan Pesta Nelayan Sebagai Daya Tarik Wisata Dalam Mempromosikan Pariwisata di Palabuhanratu Kabupaten Sukabumi”.

\section{KAJIAN PUSTAKA}

\section{A. Pariwisata}

Pentingnya peranan pariwisata dalam membangun perekonomian ini sudah tidak diragukan lagi mengingat pariwisata menjadi sektor unggulan dalam menyumbangkan devisa negara. Menurut Marpaung (2002:13), "Pariwisata adalah perpindahan sementara yang dilakukan manusia dengan tujuan keluar dari pekerjaan-pekerjaan rutin, keluar dari tempat kediamannya".

Kepariwisataan itu sendiri merupakan pengertian jamak yang diartikan sebagai hal-hal yang berhubungan dengan pariwisata, yang dalam bahasa inggris disebutkan tourism. menurut Syafiie (2009:8), "Kepariwisataan adalah suatu disiplin ilmu pengetahuan yang berdiri sendiri dewasa ini karena dapat dipelajari dan diajarkan kepada orang lain, bersifat universal dalam arti dapat diterima dalam berbagai tempat dan waktu".

Sedangkan kegiatan kepariwisataan menurut Undang-Undang Nomor 10 Tahun 2009 yaitu: "keseluruhan kegiatan yang terkait dengan pariwisata dan bersifat multidimensi serta multidisiplin yang muncul sebagai wujud kebutuhan setiap orang dan negara serta interaksi antara wisatawan dan masyarakat setempat, sesama wisatawan, pemerintah, pemerintah daerah, dan pengusaha”.

\section{B. Jenis-jenis Wisata}

Menurut Yoeti (2014:123-124), terdapat beberapa jenis pariwisata berdasarkan objeknya, yaitu:

1. Cultural Tourism, yaitu jenis pariwisata dimana motivasi orang-orang untuk melakukan perjalanan disebabkan karena adanya daya tarik seni budaya suatu tempat atau daerah. Dimana objek kunjungannya adalah tempat yang menyimpan atau tersedia benda-benda kuno ataupun situs peninggalan sejarah.

2. Recuperational Tourism, biasanya disebut sebagai pariwisata kesehatan. Tujuan dari orang-orang melakukan perjalanan adalah untuk menyembuhkan sesuatu penyakit, seperti mandi di sumber air panas, mandi lumpur seperti yang banyak di jumpai di Eropa atau mandi susu, mandi kopi di Jepang di mana dapat membuat orang menjadi lebih awet muda.

3. Commercial Tourism, disebut sebagai pariwisata perdagangan, karena perjalanan wisata ini dikaitkan dengan kegiatan perdagangan nasional atau internasional di mana sering diadakan kegiatan expo, fair, exhibition, dan lain-lain.

4. Sport Tourism, biasanya disebut dengan istilah pariwisata olahraga, yang di maksud dengan jenis pariwisata ini ialah perjalanan orang-orang yang bertujuan untuk melihat atau menyaksikan suatu pesta olahraga di suatu tempat atau negara tertentu. Seperti Olympiade, All England, pertandingan tinju atau sepak bola. Atau ikut berpartisipasi dalam kegiatan itu sendiri.

5. Political Tourism, biasanya disebut sebagai pariwisata politik, yaitu suatu perjalanan yang tujuannya untuk melihat atau menyaksikan suatu peristiwa atau kejadian yang berhubungan dengan kegiatan suatu negara.

6. Social Tourism, pariwisata sosial jarang hendaknya diasosiasikan sebagai suatu pariwisata yang berdiri sendiri. Pengertian ini hanya dilihat dari segi penyelenggaraannya saja yang tidak menekankan untuk mencari keuntungan, seperti misalnya study tour, piknik, youth tourism atau pariwisata remaja.

\section{Daya Tarik Wisata}

Menurut Undang-Undang Republik Indonesia Nomor 10 Tahun 2009 Tentang Kepariwisataan, daya tarik wisata yaitu segala 
sesuatu yang memiliki keunikan, keindahan, dan nilai yang berupa keanekaragaman kekayaan alam, budaya, dan hasil buatan manusia yang menjadi sasaran atau tujuan kunjungan wisatawan. Menurut Marpaung (2002:78), memberikan definisi mengenai "daya tarik adalah suatu tempat sebagai suatu bentukan aatau ktivitas dan fasilitas yang saling berhubungan dapat menarik wisatawan atau pengunjung untuk datang kesuatau daerah/tempat tertentu". Menurut Yoeti (2006:15), "Daya tarik wisata adalah suatu objek ciptaan Tuhan maupun hasil karya manusia, yang menarik minat orang untuk berkunjung dan menikmati keberadaannya".

Sedangkan dimensi daya tarik wisata (tourist attracions) menurut Yoeti (2010:34) yaitu:

1. Something to See. Pada setiap daya tarik wisata hendaknya selalu ada yang menarik untuk dilihat atau disaksikan, aneh, unik dan langka yang menjadi daya tarik, Artinya, ditempat tersebut harus ada daya tarik wisata dan atraksi wisata yang berbeda dengan daerah lain dan memiliki ciri khas.

2. Something to Do. Pada suatu daya tarik wisata itu, hendaknya selain banyak yang dapat dilihat atau disaksiakn, juga banyak rekreasi yang dapat dilakukan, shingga tidak monoton. Artinya, ditempat tersebut selain ada daya tarik wisata dan atraksi wisata yang dapat dinikmati, harus pula tersedia fasilitas rekreasi yang membuat wisatawan betah berada di tempat tersebut.

3. Something to Buy. Hal ini penting sekali dalam bisnis pariwisata. Wisatawan itu bisa dipisahkan dari oleh-oleh, sebagai kenangkenangan/cendera mata khas daerah karena telah datang mengunjungi ke daya tarik wisata tersebut. Artinya, ditempat tersebut/daerah tujuan wisata harus tersedia fasilitas untuk berbelanja seperti cinderamata untuk dibawa pulang ke tempat asal wisatawan.

\section{Destinasi Wisata Budaya}

Menurut Suryadana dan Octavia (2015:51) mengemukakan bahwa "destinasi pariwisata adalah area atau kawasan geografis yang berbeda dalam suatu atau lebih wilayah administrative yang di dalamnyya terdapat unsur: daya tarik wisata, fasilitas pariwisata, aksesiblitas, masyarakat serta wisatawan yang saling terikat dan melengkapi untuk terwujudnya kegiatan kepariwisataan". Sedangkan berdasarkan Undang-Undang Republik Indonesia No. 10 tahun 2009 Tentang kepariwisataan, "Daerah tujuan pariwisata yang selanjutnya disebut Destinasi Pariwisata adalah kawasan geografis yang berada dalam satu atau lebih wilayah administratif yang didalamnya terdapat daya tarik wisata, fasilitas umum, fasilitas pariwista, aksesibilitas, serta masyarakat yang saling terkait dan melengkapi terwujudnya kepariwisataan".

Dari sekian banyak daya tarik wisata, ada daya tarik wisata budaya.Menurut Ismayanti dalam Sulastri (2017:11) "daya tarik wisata budaya merupakan jenis pariwisata yang berdasarkan pada mosaik tempat, tradisi, kesenian upacara-upacara dan pengalaman memotret suatu bangsa atau suku bangsa, masyarakat, yang merefleksikan keanekaragaman (diversity) dan indentitas (karakter) dari masyarakat atau bangsa yang bersangkutan, pariwisata budaya memanfaatkan budaya sebagai potensi wisata dan budaya yang dapat dibedakan menjadi tiga wujud yaitu:

1. Gagasan (Wujud Ideal), wujud ideal kebudayaan berupa kebudayaan yang berbentuk kumpulan ide, gagasan, nilai, norma, peraturan yang bersifatnya abstrak, wujud kebudayaan terletak pada pemikiran warga masyarakat.

2. Aktivitas berupa wujud kebudayaan sebagai suatu tindakan berpola dari manusia dalam masyarakat. Wujud ini sering disebut sistem sosial, yangterdiri atas aktivitas-aktivitas manusia yang saling berinteraksi, bergaul dengan manusia lain menurut pola-pola tertentu berdasarkan adat tata kelakuan.

3. Artefak merupakan wujud kebudayaan yang berupa hasil dari aktifitas, perbuatan, dan karya manusia dalam masyarakat dengan benda-benda yang dapat diraba, dilihat, dan di dokumentasikan".

Sedangkan menurut Sunaryo (2013:26) "yang dimaksud daya tarik wisata budaya adalah daya tarik wisata yang dikembangkan dengan lebih banyak berbasis pada hasil karya dan hasil cipta manusia, baik yang berupa peninggalan budaya (heritage) maupun yang nilai budaya masih hidup (the living culture) dalam kehidupan di suatu masyarakat, yang dapat berupa: upacara/ritual, adat-istiadat, senipertunjukan, seni-kriya, seni-sastra, maupun keunikan kehidupan sehari-hari yang dipunyai oleh suatu masyarakat".

McKercher (2002:6), menjelaskan bahwa "definisi yang diteliti bukan karena kelemahan, tapi karena hampir menangkap esensi pariwisata budaya yang terdiri dari 4 unsur elemen yaitu pariwisata, penggunaan aset pusaka budaya, konsumsi produk dan pengalaman serta wisatawan budaya".

Dalam kegiatan pariwisata budaya terkadang disajikan upacara adat. Upacara adat 
menurut Koentjaraningrat (2002:377), secara khusus membaginya menjadi empat komponen utama, yaitu:

1. Tempat upacara; berkaitan dengan tempat keramat dimana upacara tersebut dilaksanakan, yaitu bisa di makam, candi, pura, kuil, gereja, masjid dan sebagainya.

2. Waktu upacara; berkaitan dengan waktuwaktu ibadah, hari-hari keramat dansuci, dan sebagainya.

3. Kelengkapan dan peralatan upacara; yaitu kelengkapan dan peralatan yangberupa barang-barang yang dipakai dalam upacara, termasuk patung-patung yang melambangkan dewa-dewa, peralatan suara seperti lonceng, suling dan sebagainya.

4. Pemimpin upacara dan pelaku upacara; seperti pendeta, biksu, dukun, dan sebagainya.

\section{E. Promosi}

Promosi menjadi salah satu aspek dari sebuah segmentasi yang dibutuhkan dan dikhususkan atas segmen target saja. Pemahaman budaya pula dapat dijadikan fondasi dalam memposisikan sebuah produk melalui iklan. Menurut Tjiptono (2002), "promosi merupakan salah satu cakupan bauran pemasaran yang penting dalam memasarkan barang atau jasa yang dihasilkan perusahaan dan juga sebagai suatu cara memberikan informasi kepada masyarakat tentang barang dan jasa yang dihasilkan perusahaan. Promosi adalah suatu bentuk komunikasi pemasaran, yaitu aktivitas pemasaran yang berusaha menyebarkan informasi, mempengaruhi, membujuk dan atau mengingatkan pasar sasaran atas perusahaan dan produknya agarkonsumen bersedia menerima, membeli, dan loyal pada produk yang ditawarkan perusahaan".

Menurut Kotler dan Keller (2009), promosi penjualan memiliki indikator -indikator sebagai berikut:

1. Frekuensi penjualan adalah jumlah promosi yang dilakukan dalam suatuwaktu melalui media promosi penjualan.

2. Kualitas promosi adalah tolak ukur seberapa baik promosi yang dilakukan.

3. Ketepatan waktu atau kesesuaian sasaran merupakan faktor yang diperlukan untuk mencapai target yang diinginkan perusahaan.

Menurut Alma (2002:145), bahwa tujuan promosi penjualan adalah sebagai berikut:

1. Menarik perhatian para pembeli baru.
2. Memberi hadiah atau penghargaan kepada konsumen atau pelanggan lama.

3. Meningkatkan daya pembelian ulang dari konsumen lama.

4. Menghindarkan konsumen dari peralihan ke merek lain.

5. Mempopulerkan merek atau meningkatkan loyalitas.

6. Meningkatkan volume penjualan jangka pendek dalam rangka memperluaspangsa pasar jangka panjang.

Lebih lanjut, menurut Daryanto (2012:104), "promosi adalah arus informasi atau persuasi satu arah yang dapat mengarahkan organisasi atau seseorang untuk menciptakan transaksi antara pembeli dan penjual". Dalam promosi terdapat beberapa kegiatan yang dilakukan, yaitu:

1. Periklanan, merupakan salah satu bentuk kegiatan promosi yang sering dilakukan perusahaan melalui komunikasi non individu dengan sejumlah biaya seperti iklan melalui media masa, perusahaan iklan, Lembaga non laba, individuindividu yang membuat poster, dan sebagainya.

2. Personel selling, adalah kegiatan promosi yang dilakukan antar individu yang sering bertemu muka yang ditujukan untuk menciptakan, memperbaiki, menguasai atau mempertahankan hubungan pertukaran yang saling menguntungkan kedua belah pihak.

3. Promosi penjualan, adalah salah satu bentuk kegiatan promosi dengan menggunakan alat peraga seperti: peragaan, pameran, demonstran, hadiah.

4. Publisitas dan humas, merupakan kegiatan promosi yang hamper sama dengan periklanan yaitu melalui media masa tetapi informasi yang diberikan tidak dalam bentuk iklan tetapi berupa berita.

\section{Metode Penelitian}

Penelitian ini menggunakan metode kualitatif yang dilakukan di Palabuhanratu Kabupaten Sukabumi. dengan menyebar kuesioner kepada masyarakat/wisatawan dan dengan mewawancarai intansi terkait menggunakan pola triangulasi, mengenai Perayaan Pesta Nelayan yang akan dianalisis menjadi suatu daya tarik wisata. Perayaan Pesta Nelayan. Menurut Moleong (2005:6), "penelitian kualitatif adalah penelitian yang bermaksud untuk memahami fenomena tentang apa yang dialami oleh subjek penelitian". Lebih 
lanjut menurut Saryono (2010:1), "Penelitian kualitatif merupakan penelitian yang digunakan untuk menyelidiki, menemukan, menggambarkan, dan menjelaskan kualitas atau keistimewaan dari pengaruh sosial yang tidak dapat dijelaskan, diukur atau digambarkan melalui pendekatan kualitatif'.

Bagian ini memuat langkah peneliti dalam melakukan penelitian, disajikan secara lengkap namun padat, mulai dari metoda pengambilan sampel sampai dengan teknik analisis.

Berada di Tempat Pelelangan Ikan (TPI) Palabuhanratu Kabupaten Sukabumi. Objek yang dijadikan penelitian atau yang menjadi titik perhatian suatu penelitian. Objek penelitian adalah festival budaya.

Adapun teknik pengumpulan data dalam penelitian ini adalah:

\section{Teknik Wawancara}

Dalam hal ini penulis akan mengadakan sesi tanya jawab atau wawancara dengan beberapa informasi kunci (Key Informan), seperti: Dinas Pariwisata Kab. Sukabumi, Dinas Kebudayaan, Pemuda, dan Olahraga Kab. Sukabumi, dan Dinas Kelautan dan Perikanan Kab. Sukabumi, Ketua Hari Nelayan, dan Tokoh Masyarakat. Didukung oleh rekaman dari hasil wawancara dengan informasi kunci.

\section{Observasi Langsung}

Dalam hal ini penulis akan mengamati di tempat penelitian mengenai fenomenafenomena yang berhubungan langsung dengan data yang akan digunakan. Lokasi observasinya di Palabuhanratu Kabupaten Sukabumi untuk mendapatkan informasi yang dibutuhkan sesuai dengan kajian dari penelitian ini.

\section{Studi Dokumentasi}

Menurut Guba dan Lincoln dalam Moloeng (2016:216), "Dokumen dan record digunakan untuk keperluan penelitian, karena alasan-alasan yang dapat dipertanggungjawabkan. Dengan demikian dokumen dan record merupakan sumber yang yang stabil, kaya dan mendorong, berguna sebagai bukti untuk suatupengujian, relative murah dan tidak sukar diperoleh, dan membuka kesempatan untuk lebih memperluas tubuh pengetahuan terhadap sesuatu yang diselidiki". Dalam hal ini studi dokumentasi yang menjadi bagian dari penelitian adalah data dokumen sekunder, foto-foto.

\section{Kuisioner}

Creswell dalam Sugiyono (2016:192), "Kuesioner merupakan teknik pengumpulan data dimana partisipan/responden mengisi pertanyaan atau pernyataan kemudian setelah diisi dengan lengkap dikembalikan kepada peneliti”. Dalam hal ini peneliti melakukan penyebaran kuesioner dengan bentuk pernyataan kepada 30 wisatawan yang pernah melakukan kegiatan perayaan pesta nelayandi Palabuhanratu Kabupaten Sukabumi.

Penelitian ini mengambil sampel di Palabuhanratu Kabupaten Sukabumi. Dalam mengumpulkan data peneliti menggunakan Triangulasi Sampling, "Triangulasi teknik, berarti peneliti menggunakan data yang berbeda-beda untuk mendapatkan data dari sumber yang sama" (Sugiyono, 2016:327). Adapun Triangulasi dalam hal ini peneliti melakukan konfirmasi data melalui tiga pihakyaitu: Pihak pertama adalah Pemerintahan dengan dua informasi kunci (Dinas Pariwisata Kabupaten Sukabumi, Dinas Kebudayaan, Pemuda, dan Olahraga Kabupaten Sukabumi, dan Dinas Perikanan dan Kelautan Kabupaten Sukabumi), Pihak kedua adalah pelaku usaha/praktisi dengan dua informasi kunci (Kecamatan Palabuhanratu dan Ketua Pelaksana Festival Hari Nelayan Palabuhanratu Kab. Sukabumi), Pihak ketiga Tokoh Masyarakat.

TABEL 1. INFORMASI KUNCI (KEY INFORMAN)

\begin{tabular}{|c|c|c|c|}
\hline $\mathrm{NO}$ & $\begin{array}{c}\text { KEY } \\
\text { INFORMAN }\end{array}$ & SUMBER & $\begin{array}{c}\text { INFORMASI } \\
\text { YANG DI } \\
\text { DAPAT }\end{array}$ \\
\hline 1 & $\begin{array}{c}\text { Dinas } \\
\text { Pariwisata } \\
\text { Kabupaten } \\
\text { Sukabumi } \\
\end{array}$ & $\begin{array}{c}\text { Pejabat } \\
\text { Dinas } \\
\text { Pariwisata }\end{array}$ & \multirow{5}{*}{$\begin{array}{l}\text { - Tentang } \\
\text { Penyelengga } \\
\text { raan } \\
\text { Pariwisata } \\
\text { Budaya } \\
\text { Pesta } \\
\text { Nelayan } \\
\text { - Tentang } \\
\text { Daya Tarik } \\
\text { Wisata } \\
\text { Kegiatan } \\
\text { Pesta } \\
\text { Nelayan } \\
\text { - Tentang } \\
\text { Efektifitas } \\
\text { Promosi } \\
\text { Daya Tarik } \\
\text { Wisata Pesta } \\
\text { Nelayan }\end{array}$} \\
\hline 2 & $\begin{array}{c}\text { Dinas } \\
\text { Kebudayaan, } \\
\text { Pemuda, dan } \\
\text { Olahraga } \\
\text { Kabupaten } \\
\text { Sukabumi } \\
\end{array}$ & $\begin{array}{l}\text { Pejabat } \\
\text { Dinas } \\
\text { Budpora }\end{array}$ & \\
\hline 3 & $\begin{array}{c}\text { Pelabuhan } \\
\text { Perikanan } \\
\text { Nusantara } \\
\text { Palabuhanratu } \\
\text { (PPNP) } \\
\text { Kabupaten } \\
\text { Sukabumi } \\
\end{array}$ & $\begin{array}{l}\text { Pejabat } \\
\text { PPNP }\end{array}$ & \\
\hline 5 & $\begin{array}{c}\text { Ketua } \\
\text { Pelaksana Hari } \\
\text { Nelayan } \\
\end{array}$ & $\begin{array}{c}\text { Ketua } \\
\text { Pelaksana }\end{array}$ & \\
\hline 6 & $\begin{array}{c}\text { Tokoh } \\
\text { Masyarakat }\end{array}$ & Wisatawan & \\
\hline
\end{tabular}

Sumber: Olahan Peneliti (2017)

Menurut Miles dan Huberman dalam Sugiyono (2016:334), "analisis data adalah proses proses analisis kualitatif yang mendasarkan pada adanya hubungan sistematis antar variabel yang sedang diteliti dan menjelaskan aktifitas dalam analisis data selama di lapangan", dimana terdapat 3 bagian dalam proses analisisnya yaitu: 


\section{Reduksi Data}

Data yang diperoleh dirangkum, lalu di pilih hal-hal yang pokok, memfokuskan pada hal-hal yang penting, dicari tema dan polanya. Dengan demikian data yang telah direduksi akan memberikan gambaran yang jelas dan mempermudah peneliti untuk melakukan pengumpulan data selanjutnya dan mencarinya bila perlu.

\section{Penyajian Data}

Setelah data direduksi, maka langkah selanjutnya adalah menampilkan data. Penyaji data adalah kegiatan ketika sekumpulan informasi disusun, sehingga memberi kemungkinan akan adanya penarikan kesimpulan. Dalam penelitian kualitatif penyajian data bisa dilakukan dengan bentuk uraian singkat, bagan, hubungan, antar kategori, Flowchart dan sejenisnya. Dengan menampilkan data maka akan memperoleh untuk memahami apa yang terjadi, merencanakan kerja selanjutnya berdasarkan apa yang telah dipahami tersebut

\section{Penarikan Kesimpulan}

Langkah selanjutnya adalah pengambilan kesimpulan dan verifikasi. Kesimpulan awal yang dikemukakan masih bersifat sementara dan akan berubah bila tidak ditemukan bukti-bukti yang mendukung pada tahap pengumpulan data berikutnya. Tetapi apabila kesimpulan yang dikemukakan pada tahap awal, didukung oleh bukti-bukti yang valid dan konsisten saat peneliti kembali ke lapangan mengumpulkan data, maka kesimpulan yang dikemukakan merupakan kesimpulan yang kredibel. Hasil data dari kuesioner dan wawancara diolah dan dibahas oleh peneliti sehingga menghasilkan interpretasi data dan selanjutnya disimpulkan secara jelas dan eksplisit.

\section{HASIL PENELITIAN DAN PEMBAHASAN}

A. Gambaran Penyelenggaraan Pesta Nelayan di Palabuhanratu Kabupaten Sukabumi

Berdasarkan hasil penelitian melalui studi dokumentasi, kuesioner dan wawancara kepada informan kunci juga wisatawan dapat diketahui bahwa penyelenggaraan pesta nelayan di Palabuhanratu Kabupaten Sukabumi sebagai berikut:

\section{Tingkat kemenarikan pariwisata budaya}

Berdasarkan observasi, dan wawancara dengan wisatawan dapat disimpulkan bahwa pariwisata budaya yang ada di Palabuhanaratu, sangat menarik karena yang diangkat merupakan sebuah cerita toponomi yang dapat menarik orang untuk datang ke Palabuhanratu.
Selain itu, hari nelayan sudah terlaksana cukup lama dan masih bisa eksis seiring perkembangan teknologi dan budaya luar yang masuk ke daerah. Bahkan kegiatan hari nelayan ini merupakan kegiatan yang ditunggu oleh wisatawan yang berwisata ke Palabuhanratu untuk menyaksikan dan sengaja setiap tahunnya untuk datang karena kegiatan ini sangat menarik walaupun ada di beberapa daerah tetapi di Palabuhanratu yang paling meriah. Berdasarkan hasil wawancara dengan informan kunci (Inf. 01 dan 04) dapat disimpulkan bahwa kemenarikannya dikarenakan adanya kepastian terhadap tanggal kegiatan yaitu pada tanggal 6 April sebagai hari nelayan nasional. Kemenarikan lainnya yaitu ada upacara adat, pagelaran budaya beserta rombongan parade putri nelayan dan pemangku adat, juga ada labuh saji yang sesajennya dilepas ke tengah laut beserta para rombongan pagelaran budaya dan wisatawan.

\section{Tingkat kemenarikan konsep pariwisata budaya}

Berdasarkan hasil observasi, dan wawancara kepada wisatawan bahwa konsep pariwisata budaya yang menarik itu di ritual mistisnya dikemas dengan baik sehingga acara yang terselenggara dengan menarik. Kemudian tetap diadakan pemilihan putri nelayan sebagai ikon dari perayaan pesta hari nelayan. Namun demikin, masih ada kekurangan yaitu dalam pemilihan puteri nelayan dirasakan masih kontroversial.

\section{Tingkat konsistensi pelaksanaan tradisi originilitas}

Berdasarkan hasil wawancara dan observasi kepada informan kunci (Inf. 01, 02, dan 04) menerangkan bahwa konsistensi pelaksanaan tradisi originalitas sekarang sudah mulai ada perubahan karena tergantung dari yang memegang acaranya atau yang sering disebut event organizer dan saat ini sudah mulai bergeser esensinya karena dipadukan dengan orang modern saat ini. Kemudian pelaksanaannya selain pemotongan kepala kerbau ada pelepasan penyu atau tukik guna melestarikannya karena sekarang penyelenggara lebih melihat ke sisi lain yaitu pelestarian biota dan kehidupan bawah laut. Namun untuk beberapa tahun kebelakang ritualnya tidak di ekspos seperti dulu karena pada saat kepemimpinan Bupati saat ini harus dikurangi karena dikhawatirkan ada kegiatan yang bertentangan dengan agama. Dapat disimpulkan bahwa tingkat konsistensi itu tergantung dari pendanaan, kreativitas panitia, pemimpin daerah dan berjalan sesuai waktu dan rencana. 


\section{Tingkat kesan dalam berwisata}

Berdasarkan hasil observasi, dan wawancara kepada wisatawan dapat disimpulkan bahwa wisatawan sangat menikmati acara tersebut sehingga dapat menimbulkan kesan berwisata yang sangat baik dan membuat wisatawan ingin kembali datang dan melihat rankaian kegiatan pada perayaan pesta nelayan. Wisatawan juga excited jika sudah memasuki bulan yang dimana ada pelaksanaan event besar tahunan. Negatif nya adalah harga makanan atau minuman yang dijual terkadang bisa sampai tiga kali lipat dari harga pasaran, begitu pula dengan cinderamata yang dijual.

5. Tingkat pengelompokan segmen wisatawan

B. Gambaran Daya Tarik Wisata Kegiatan Hari Nelayan

Berdasarkan hasil penelitian melalui studi dokumentasi, kuesioner dan wawancara kepada informan kunci juga wisatawan dapat diketahui bahwa daya tarik wista kegiatan hari nelayan di Palabuhanratu Kabupaten Sukabumi sebagai berikut:

\section{Tingkat kemenarikan atraksi yang ditampilkan}

Berdasarkan hasil observasi dan wawancara kepada wisatawan dapat disimpulkan bahwa atraksi yang ditampilkan sangat menarik karena adanya perahu nelayan yang disewa wisatawan untuk dapat mengikuti kegiatan di tengah laut seperti pelepasan labuh saji, lalu bazar selama dua bulan dan diadakan pagelaran seni salah satunya tradisi tarian dog-doglojor yang asli dari Kab. Sukabumi. Selain itu wisatawan juga dapat menyaksikan pelepasan penyu atau tukik.

2. Tingkat atraksi yang dapat dinikmati secara langsung

Berdasarkan observasi dan wawancara kepada wisatawan bahwa atraksi yang dapat dinikmati secara langsung menarik karena wisatawan dapat ikut ke tengah laut dengan menyewa perahu dan menyaksikan acara labuh saji selain itu juga wisatawan dapat berenang dan mengambil labuh saji yang dibuang kelaut. Berdasarkan wawancara kepada informan kunci dapat disimpulkan bahwa ada beberapa kegiatan yang dapat diikuti oleh masyarakat lomba congkreng perahu nelayan tradisional, arung gelombang, dan lain-lain.

3. Tingkat pendukung dari kegiatan pariwisata yang dapat dibeli

Berdasarkan observasi dan wawancara kepada wisatawan bahwa pendukung dari kegiatan pariwisata yang dapat dibeli menarik, karena cinderamata dan makanan khas Palabuhanratu sudah banyak ditemukan seperti miniatur perahu, miniatur papan surfing, batik khas Kab. Sukabumi, abon ikan marlin, bakso ikan, dan lain-lain. Berdasarkan hasil wawancara kepada informan kunci (In. 03) dapat disimpulkan bahwa seharusnya kegiatan pendukung seperti cinderamata khas Kab. Sukabumi selalu ada dalam kegiatan pamera karena Kab. Sukabumi juga memiliki banayak cinderamata seperti: miniatur perahu bagang dan miniatur peralatan wisata bahari, gula aren, bakso ikan, abon ikan, gantungan kunci berbentuk penyu, batik khas Sukabumi dan lainlain.

\section{Gambaran Efektifitas Promosi Daya Tarik Wisata Hari Nelayan}

Berdasarkan hasil penelitian melalui studi dokumentasi, kuesioner dan wawancara kepada informan kunci juga wisatawan dapat diketahui bahwa efektifitas promosi daya tarik wisata hari nelayan di Palabuhanratu Kabupaten Sukabumi sebagai berikut:

\section{Tingkat frekuensi pelaksanaan kegiatan}

Berdasarkan hasil wawancara kepada informan kunci (Inf. 01, 02, 03, dan 04) dapat disimpulkan bahwa frekuensi pelaksanaan kegiatan dilaksanakan selama dua bulan penuh dari mulai tanggal 14 Februari sampai 16 April.namun kegiatan hari nelayan ini belum optimal, karena event yang sudah rutin dilaksanakan seharusnya sudah bisa ketingkat nasional yang dapat dipromosikan oleh Kemenpar.

\section{Tingkat kualitas promosi yang dilakukan}

Berdasarkan hasil wawancara kepada wisatawan bahwa kualitas promosi yang dilakukan pemerintah sudah baik, saat ini zamannya teknologi sehingga jangkauannya lebih luas lagi karena saat ini hanya mencakup masyarakat Kab. Sukabumi akan tetapi dari tahun ke tahun sudah ada perkembangan dalam mempromiskan kegiatannya, selain itu informasi yang didapat sebagian besar berasal dari komunitas yang bekerjasama dengan pemerintah dan dinas penyelengga, dan media sosial masyarakat. Tahun 2018 ini pengunjung yang datang dalam mengikuti kegiatan hari nelayan ini lebih banyak daripada tahun sebelumnya.

3. Tingkat konsistensi terhadap pelaksanaan promosi

Berdasarkan hasil wawancara kepada informan kunci (In. 02, dan 03) dapat disimpulkan bahwa konsistensi terhadap pelaksanaan promosi sudah konsisten seperti: media promosi, media cetak, media sosial atau online diantaranya seperti Instagram, facebook, twitter, website, dll. Akan tetapi semua itu baru 
di mulai pada awal tahun 2017 dan saat ini penggunaan untuk media promosinya sedang dioptimalkan lagi, selain itu promosi dilakukan dengan cara mengikuti event di tempat lainnya seperti pameran. Namun demikian, belum ada evaluasi menyeluruh atas efektivitas promosi yang dilakukan.

\section{KESIMPULAN}

Secara keseluruhan hasil penelitian mengenai penyelenggaraan pariwisata budaya pesta nelayan sangat menarik bagi wisatawan disebabkan kegiatan tersebut bertepatan dengan hari nelayan nasional dan diadakan satu tahun sekali. Faktor lain kemenarikannya karena ada upacara adat, pagelaran budaya beserta rombongan parade putri nelayan dan pemangku adat, juga ada labuh saji yang sesajennya dilepas ke tengah laut beserta para rombongan pagelaran budaya dan pengunjung. Selain itu kegiatan tersebut dibumbui oleh ritual mistik yang dikemas dengan menarik. Namun untuk beberapa tahun kebelakang ritualnya tidak di ekspos seperti dulu karena pada saat kepemimpinan Bupati saat ini harus dikurangi karena dikhawatirkan ada kegiatan yang bertentangan dengan agama.

Secara keseluruhan hasil penelitian mengenai daya tarik wisata yang ada pada saat kegiatan pesta nelayan tersebut yaitu ada beberapa atraksi di antaranya pelepasan tukik atau penyu, labuh saji, pagelaran budaya, bazar, dan berbagai perlombaan. Namun demikian daya tarik wisata tersebut dalam penyelenggaraan bazar yang disajikan tidak mencerminkan kekhususan atau keunikan daerah, jadi bazar tersebut sama dengan bazar yang ada pada umumnya. Kalaupun ada penjualan cenderamata daerah seperti miniatur perahu, miniatur alat bahari, gantungan kunci berbentuk penyu, makanan khas daerah seperti bakso ikan, abon ikan marlin, gula aren, ini pun dijual di luar stand bazar.

Secara keseluruhan hasil penelitian mengenai efektifitas promosi yang dilakukan pemerintah sudah baik dengan menggunakan media sosial (Instagram, facebook, dan lainlain) sehingga jangkauannya sangat luas. Di mana di tahun-tahun sebelumnya kegiatan promosi hanya mengandalkan laman (website) dan media cetak semata. Namun demikian, belum ada evaluasi menyeluruh atas efektivitas promosi yang dilakukan.

\section{DAFTAR RUJUKAN}

Alfan, M. (2013). Filsafat Kebudayaan. Bandung: CV Pustaka Setia.

Alma. (2002). Manajemen Pemasaran dan Pemasaran Jasa. Bandung: Alfabeta.
Daryanto. (2012). Manajemen Pemasaran. Bandung: PT Sarana Tutorial Nurani Sejahtera.

Daryanto, \& Abdullah. (2013). Pengantar Ilmu Manajemen dan Komunikasi. Prestasi Pustaka Raya.

Edison, E., Anwar, Y., \& Imas, K. (2016). Manajemen Sumber Daya Manusia. Bandung: Alfabeta.

Emron, Yohny, \& Imas. (n.d.). Manajemen Sumber Daya .

Hendri, M. (2006). Pemasaran Ritel. Jakarta: Gramedia Pustaka Utama.

Herusatoto. (2001). Simbolisme Dalam Budaya Jawa. Yogyakarta: Hanindita.

Ismayanti. (2010). Pengantar Pariwisata. Bandung: Alfabeta.

Kementerian Kelautan dan Perikanan. (2015). Jawa Barat Merentang Laut Jawa Hingga Samudra Hindia. Jakarta: PT Kompas Media Nusantara.

Kertamukti, R. (2015). Strategi Kreatif dalam Periklanan. Jakarta: PT RajaGrafindo Persada.

Koentjaraningrat. (2002). Kebudayaan Mentalitas dan Pembangunan. Jakarta: PT. Gramedia.

Kotler, \& Keller. (2009). Manajemen Pemasaran. Jakarta: Erlangga.

Lesmana, A. C., Edison, E., Dara, A. (2017). Tourism Scientific Journal: PemberdayaanMasyarakat Di Destinasi Wisata Tebing Keraton Kampung Ciharegem Puncak Desa Ciburial Kabupaten Bandung

Marpaung, H., \& Bahar, H. (2002). Pengantar Pariwisata. Bandung: Alfabeta.

McKercher, B., \& Cros, H. D. (2002). Cultural Tourism. New York: Routledge Taylor \& Francis Group.

Moleong. (2005). Metode Kualitatif Edisi Revisi. Bandung: PT Remaja Rosdakarya.

Moleong, L. J. (2015). Metodologi Penelitian Kualitatif. Bandung: PT Remaja Rosdakarya Bandung.

Pitana, I., \& Diarta, I. (2009). Pengantar Ilmu Pariwisata. Yogyakarta: Muhammad Andi Kesrul.

Pradja, J. (2013). Filsafat Kebudayaan. Bandung: Pustaka Setia.

Saryono. (2010). Metodologi Penelitian Kualitatif. Bandung: Alfabeta.

Sedarmayanti. (2014). Membangun dan Mengembangkan Kebudayaan dan Industri Pariwisata (Bunga Rampai Tulisan Pariwisata). Bandung: PT Refika Aditama. 
Sugiyono. (2012). Metode Penelitian Kuantitatif Kualitatif dan R\&D. Bandung: Alfabeta.

Suharsaputera. (2014). Metode Penelitian Kuantitatif, Kualitatif. Refika Aditama.

Sujarweni, V. (2015). Metodologi Penelitian Bisnis dan Ekonomi. Yogyakarta: PUSTAKABARUPRESS.

Sunaryo, B. (2013). Kebijakan Pembangunan Destinasi Pariwisata Konsep dan Aplikasinya Di Indonesia. Yogyakarta: PENERBIT GAVA MEDIA.

Syafiie, I. K. (2009). Pengantar Ilmu Pariwisata. Bandung: CV. Mandar Maju.

Tjiptono, F. (2002). Strategi Pemasaran. Yogyakarta: Andi.

Tjiptono, F. (2008). Strategi Pemasaran. Yogyakarta: Andi.

Widodo, S. (2014). Pengantar Manajemen. Bandung.

Wilujeng. (2007). Pengantar Manajemen. Graha Ilmu.

Yoeti, O. A. (2006). Ilmu Pariwisata. Jakarta: PT. Perca.

Yoeti, O. A. (2010). Dasar-DAsar Pengertian Hospitality dan Pariwisata. Bandung: P.T. Alumni.

Yoeti, O. A. (2014). Pengantar Ilmu Pariwisata. Bandung: Angkasa.

Abdurrohman, M. (2015). The Messenger, Volume VII Nomor 1. Memahami MaknaMakna Simbolik Pada Upacara Adat Sedekah Laut, hal 27-28.

Canavan, B. (2016). Tourism Management, Vol. 53. Tourism Culture Nexus, Characteristic, Context and Sustainability.

Santa-Cruz, G.F., \& Lopez-Guzman, T. Tourism Management Perspectives, Vol.
24. Culture, Tourism, and World Heritage Sites.

Asmarani, D. (2017). Pengelolaan Situs Megalitikum Gunung Padang Sebagai Daya Tarik Wisata Cagar Budaya Di Kabupaten Cianjur. STIEPAR BANDUNG.

Barros, A. D. (2014). Pengembangan Daya Tarik Wisata Air Terjun Mota Bandera Atsabe Di Distrik Ermera Timor Leste. Bandung: STIEPAR BANDUNG.

Gultom, E. (2017). Strategi Pelestarian Tari Patung Si Gale-Gale Sebagai Daya Tarik Wisata Budaya Di Desa Tomok Kabupaten Samosir. Bandung: STIEPAR BANDUNG.

Reza, T. M. (2014). Pengembangan Potensi Alam Sungai Citarik Hilir Sebagai Daya Tarik Wisata Minat Khusus Rafting di Desa Pasir Suren Palabuhanratu Kabupaten Sukabumi. Bandung, Jawa Barat: STIEPAR YAPARI BANDUNG.

Sulastri, N. (2017). Pelestarian Upacara Adat Nyangku Sebagai Daya Tarik Wisata Budaya Di Desa Panjalu. Bandung: STIEPAR BANDUNG.

Supriyanto, M. (2008, Agustus 7). Potensi dan Daya Tarik Wisata Pantai Pasir Putih Srau Pacitan. Surakarta: UNIVERSITAS SEBELAS MARET SURAKARTA.

Tjahyadi, T. (2017). Pengaruh Implementasi Sapta Pesona Terhadap Minat Rekreasi di Taman Balaikota Bandung. Bandung: STIEPAR YAPARI BANDUNG.

Wahyudi, A. (2017). Pengaruh Kompetensi Pemandu Arung Jeram Terhadap Kepuasan Wisatawan di Sungai Citarik Kabupaten Sukabumi. Bandung: STIEPAR YAPARI BANDUNG. 
